\title{
Population genetic structure in a deepwater fish Coryphaenoides rupestris: patterns and processes
}

\author{
Halvor Knutsen $^{1,2,3, *}$, Per Erik Jorde ${ }^{2}$, Odd Aksel Bergstad ${ }^{1}$, Morten Skogen ${ }^{4}$ \\ ${ }^{1}$ Institute of Marine Research, Flødevigen, 4817 His, Norway \\ ${ }^{2}$ Centre for Ecological and Evolutionary Synthesis (CEES), Department of Biology, University of Oslo, \\ PO Box 1066 Blindern, 0316 Oslo, Norway \\ ${ }^{3}$ University of Agder, 4604 Kristiansand, Norway \\ ${ }^{4}$ Institute of Marine Research, 5817 Bergen, Norway
}

\begin{abstract}
We observed significant genetic structure in a widely distributed North Atlantic demersal deepwater fish, the roundnose grenadier Coryphaenoides rupestris (Pisces: Macrouridae). The overall estimate of genetic differentiation, based on 6 microsatellite loci $\left(F_{\mathrm{ST}}=0.0152\right.$; $p<0.0001$ ), was elevated by samples from the periphery of the species' range, off Norway and Canada. Samples from the central area of distribution showed less pronounced genetic structure, indicating more extensive dispersal and gene flow. Simulations were run to assess expected patterns of genetic differentiation under 2 major hypotheses of gene flow: passive larval drift and demographic diffusion. In spite of the relatively long duration of the pelagic egg and juvenile phases, no correlation was found between observed pairwise $F_{\mathrm{ST}}$ values and those predicted under the hypothesis of drift of progeny by ocean currents. The observed pattern may instead arise from a combination of bathymetric barriers limiting deep pelagic mixing and advection, early life ontogenetic changes in vertical distribution, and limited migration once a benthopelagic life style has been established.
\end{abstract}

KEY WORDS: North Atlantic $\cdot$ Roundnose grenadier $\cdot$ Macrouridae $\cdot$ Connectivity $\cdot$ Genetics $\cdot$ Dispersal modeling

Resale or republication not permitted without written consent of the publisher

\section{INTRODUCTION}

Marine populations were until quite recently assumed to represent open systems with pronounced gene flow as a result of high levels of dispersal during early life stages (for review, see Caley et al. 1996). However, observations of genetically and demographically structured populations of many marine species, including species with considerable long-range dispersal potential, suggest that the openness assumption may not be generally valid (Jones et al. 1999, Cowen et al. 2006, Almany et al. 2007, Jorde et al. 2007, Planes et al. 2009). These findings have catalyzed new studies on largely unclear underlying structuring mechanisms and pro- cesses (Pineda et al. 2007). Nevertheless, very few studies actually combine data from several sources with the aim of proposing mechanisms sustaining population structure (but see Ciannelli et al. 2010, Selkoe et al. 2010).

The benthopelagic roundnose grenadier Coryphaenoides rupestris of the predominantly deepwater teleost family Macrouridae inhabits continental, island, and seamount slopes of the North Atlantic and the mid-Atlantic Ridge. Shibanov \& Vinnichenko (2008) summarized the existing theories and data on population structure of the roundnose grenadier and concluded that there is no consensus on the issue. Stock structure schemes adopted by The International Council for the Exploration of the Sea (ICES) 
for management purposes are tentative and based on assumed rather than documented population separation between subareas where fisheries occur (Lorance et al. 2008). Previous studies detected significant genetic differences between populations sampled on the continental slopes of the NE and NW Atlantic (isozyme studies by Logvinenko et al. 1983 and Dushchenko \& Savvatimskii 1987), and between 2 sites on the mid-Atlantic Ridge north and south of the Charlie-Gibbs Fracture Zone (microsatellite study by White et al. 2010). These previous genetic studies considered only limited parts of the species' basin-wide distribution area. Here, we extend the geographic range of sampling to the entire geographic distribution area and combine genetic (microsatellite) data with information on potential structuring forces such as ocean circulation patterns and bathymetry and configuration of landmasses. This is equivalent to a 'landscape' genetic approach which has proven successful in revealing mechanisms underlying genetic structure in several shallow-water fishes (Manel et al. 2003, Jørgensen et al. 2005, Kenchington et al. 2006, McCairns \& Bernatchez 2008).

Identification and delineation of populations is central in ecology (Waples \& Gaggiotti 2006), and a key challenge is understanding mechanisms underlying observed population structure and distribution patterns, i.e. what processes that facilitate or prevent connectivity over the species' range. In the case of deepwater fish that are utilized commercially, the need for population structure information has been recognized for a long time. Accordingly, the present study had a 2-fold aim, i.e. (1) to analyze population structure and propose structuring mechanisms of a widely distributed deepwater fish inhabiting continental slopes and midocean ridges, and (2) to enhance the quality of advisory efforts on the roundnose grenadier as a prominent commercially exploited species of the North Atlantic (e.g. Lorance et al. 2008).

\section{MATERIALS AND METHODS}

\section{Species}

The roundnose grenadier lives in the North Atlantic at 180 to 2200 m (Geistdoerfer 1986). It is widely distributed on the continental slopes from Spain to north Norway in the East Atlantic (Geistdoerfer 1986), from north of the Azores to Iceland in the Mid-Atlantic (Bergstad et al. 2008), and from Cape Hatteras to Baffin Island and East Greenland in the West Atlantic (Atkinson 1995). It also occurs in Norwegian fjords and continental shelf troughs, including the deep Skagerrak (NE North Sea, Eliassen 1983, Bergstad 1990; Fig. 1). The species first became targeted as a fishery resource in 1967 in the Northwest Atlantic (Atkinson 1995), and later fisheries developed in other parts of the range. In slope waters of the NE Atlantic (ICES Areas VI, VII, Vb), the spawning biomass may have fallen to approximately $30 \%$ of that of the virgin stocks (ICES 2002). The fisheries developed prior to the introduction of exclusive economic zones and decades before the currently enforced regulations. The majority of roundnose grenadiers presently fished in NE Atlantic are 18 yr old or younger, but the species can become substantially older, and the oldest individual recorded was 72 yr (Bergstad 1990). Females mature at 8 to 10 yr old (Bergstad 1990), which is relatively late compared to typically exploited fishes from shallower waters.

Adult roundnose grenadiers have been recorded in all parts of the distribution area, and spawning is most likely geographically widespread (Atkinson 1995). Several studies report spawning in late

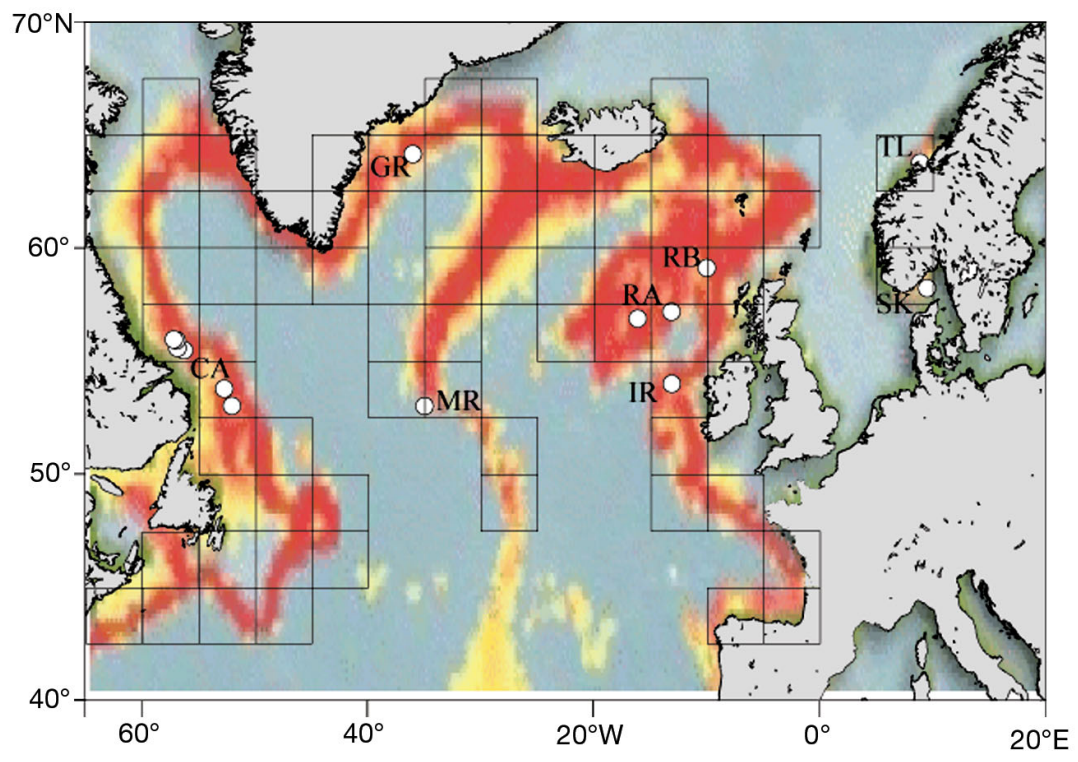

Fig. 1. Coryphaenoides rupestris. Distribution of roundnose grenadier throughout the North Atlantic. Expected distribution is modified from www.fishbase.org (Froese \& Pauly 2000); relative probability of occurrence ranges from 0.01-0.19 (pale yellow) to 0.8-1.00 (red). Open circles mark sample sites (see Table 1 for abbreviations and details), and grid squares (cf. Fig. 2) represent hypothetical 'populations' used in computer simulations 
Table 1. Coryphaenoides rupestris. Samples and sample localities of roundnose grenadier. For each sample, the table presents the abbreviated name, the sample position (latitude and longitude, in decimal degrees), the number of fish sampled, their average weight and pre-anal fin length, and the depth range of the collection. na: not available

\begin{tabular}{|c|c|c|c|c|c|c|c|c|}
\hline \multirow[t]{2}{*}{ Sample locality } & \multirow{2}{*}{$\begin{array}{l}\text { Abbre- } \\
\text { viation }\end{array}$} & \multicolumn{2}{|c|}{ Position } & \multirow{2}{*}{$\begin{array}{l}\text { Sample } \\
\text { size } \\
\text { (n) }\end{array}$} & \multirow{2}{*}{$\begin{array}{l}\text { Ungutted } \\
\text { weight }(g) \\
\text { mean (SD) }\end{array}$} & \multirow{2}{*}{$\begin{array}{c}\text { Pre-anal } \\
\text { fin length }(\mathrm{cm}) \\
\text { mean }(\mathrm{SD})\end{array}$} & \multirow[t]{2}{*}{ Depth (m) } & \multirow[t]{2}{*}{ Date } \\
\hline & & Lat. & Long. & & & & & \\
\hline \multirow[t]{2}{*}{ Skagerrak } & SK01 & 58.377 & 9.910 & 96 & $462(272)$ & $12.9(2.42)$ & $490-520$ & Nov 01 \\
\hline & SK08 & 58.377 & 9.910 & 96 & 315 (135) & $11.1(1.85)$ & $380-500$ & Feb 08 \\
\hline Trondheimsleia & TL & 64.200 & 5.600 & 99 & $926(182)$ & $17.5(1.43)$ & $300-350$ & Aug 04 \\
\hline \multirow[t]{2}{*}{ Rockall } & RA06 & 57.229 & -13.015 & 96 & 442 (239) & $12.53(2.06)$ & $300-850$ & Nov 06 \\
\hline & RA07 & 56.855 & -16.005 & 96 & 889 (432) & $15.93(3.18)$ & 950 & Nov 07 \\
\hline Rosemary Bank & $\mathrm{RB}$ & 59.090 & -10.002 & 91 & na & $19.61(2.04)$ & 900 & Sep 07 \\
\hline \multirow[t]{3}{*}{ Irish slope } & IR & 62.500 & -3.160 & 22 & & & na & Nov 06 \\
\hline & & 61.800 & -4.110 & 25 & $550(299)$ & $14.26(2.83)$ & & Nov 06 \\
\hline & & 61.901 & -3.010 & 49 & & & & Nov 06 \\
\hline Mid-Atlantic Ridge $^{\mathrm{a}}$ & MR & 52.976 & -34.869 & 96 & 267 (323) & $9.7(0.4)$ & $1237-1296$ & Jul 04 \\
\hline Greenland & GR & 64.200 & -36.000 & 55 & $342.2(275)$ & $11.11(4.61)$ & $1090-1114$ & Jun 03 \\
\hline Canada & $\mathrm{CA}$ & 55.447 & -56.063 & 96 & na & $10.31(2.24)$ & $632-1736$ & Oct/Nov 04 \\
\hline
\end{tabular}

autumn and mid-winter, but timing and duration may vary between subareas (Bergstad 1990 and references therein). Most subareas of the range are connected by continuous slopes or ridges with depths corresponding with the depth distribution observed for the species. The general openness of the majority of the species' range might be expected to facilitate dispersal by migration. Exceptions may be apparently isolated spawning areas separated by shallow sills in Norwegian fjords and in the Skagerrak (Bergstad \& Gordon 1994). However, the grenadier is presumed to have restricted adult dispersal capability (e.g. Shibanov \& Vinnichenko 2008), and there is no evidence of major horizontal migration.

There is no comprehensive understanding of egg and larval drift throughout the distribution area of the species, but some information exists on vertical and horizontal distribution of pelagic juveniles in specific subareas. Eggs are presumably spawned near the seabed but become epipelagic $(0-200 \mathrm{~m}$ depth) or mesopelagic (200-1000 m). In the Skagerrak, eggs were observed in the autumn at 150 to $500 \mathrm{~m}$, mainly at 200 to $350 \mathrm{~m}$, but not in the upper epipelagic zone (Bergstad \& Gordon 1994). The early juvenile stages also occur mesopelagically, but at increasing depths with increasing body size (Merrett 1978, Bergstad \& Gordon 1994). In the Skagerrak, most juveniles had become demersal after 6 to $7 \mathrm{mo}$, but timing and duration of the pelagic juvenile period presumably vary over the range of the species. The species undertakes extensive seasonal and diurnal migrations up and down slopes, and into the water column, presumably to forage (Pechenik \& Troyanovsky 1971, Haedrich 1974, Bergstad 1990).
The long pelagic phase suggests that the roundnose grenadier has considerable potential for passive dispersal by ocean currents during the early life stages (e.g. Scott \& Scott 1988). In extensive surveys of the mid-Atlantic and the Irminger Sea, Vinnichenko \& Khlivnoy (2008) claimed that observations of mesopelagic juveniles above the mid-Atlantic Ridge and in the Irminger Sea, where the bottom depth is 1200 to $3200 \mathrm{~m}$, do support extensive 'passive migrations' during the early life stages. However, most other studies indicate that catches of mesopelagic juveniles are closely related to areas where demersal juveniles and adults are also abundant. Hence, larval drift remains a potential but so far untested hypothetical mechanism for gene flow and population connectivity in the roundnose grenadier.

\section{Sampling}

In total, 917 specimens of Coryphaenoides rupestris were made available for the genetic studies (courtesy of a number of colleagues and projects). All were sampled by bottom trawls on research vessels and were large specimens that had attained the demersal life style. The samples represented 8 localities spanning the North Atlantic distribution area of the species (cf. Fig. 1, Table 1). From 2 of the localities, Skagerrak and Rockall, temporal replicates were available. The Rockall replicates were sampled on either side of the bank and were perhaps too distant to be regarded as stringent temporal replicates. In addition to sampling position, date, and depth, most samples also had data on individual pre-anal fin 
length and body weight (cf. Table 1). White skeletal muscle was collected from fresh specimens and preserved in $96 \%$ ethanol at sea, or newly caught fish were frozen immediately on board ship and prepared later on, in the laboratory.

\section{Genetic analysis}

DNA was extracted from ethanol-preserved muscle tissue, using a Viogene extraction kit. We applied Eppendorf 5 Prime Taq DNA polymerase for the PCR reactions, using the supplied self-adjusting magnesium $10 \times$ buffer. Screenings of 8 microsatellites, Crup 1 through 8 , were carried out using published protocols (Knutsen et al. 2008), and separated using a capillary CEQ 8000 (Beckmann) automated sequencer. Seven of the 8 loci were easy to score and generally of high quality. One locus (Crup5) was highly polymorphic and displayed a moderate PCR stuttering. Several PCR re-runs were performed for this locus to ensure consistent genotype scorings. To minimize genotyping errors, all interpretations of fragments were scored independently by 2 trained observers. Disagreements were re-analyzed repeating the PCR in order to avoid misclassification of alleles and genotypes. Genotypes that remained uncertain after replicate PCR and separation runs were omitted from further considerations. We applied Microchecker (Van Oosterhout et al. 2004) to test for large allele drop-out, stuttering, or null alleles. Potential null alleles were detected at 2 loci (Crup 4 and Crup7) in several samples; we therefore ignored these 2 loci and used the remaining 6 in all further statistical tests and estimates.

\section{Statistical analysis}

Genetic variability was characterized at each locus and averaged over loci by gene diversity $H_{\mathrm{T}}$ (Nei \& Chesser 1983) and number of alleles at each locus. Deviations from Hardy-Weinberg (H-W) genotype proportions were estimated by $F_{\mathrm{IS}}$ (Weir \& Cockerham 1984) and tested (2-sided probability test) with the GENEPOP software (ver. 4.0: Rousset 2008). In order to control type I statistical errors in multiple tests, we applied the false discovery rate (FDR) approach of Benjamini \& Hochberg (1995). That is, the ordered p-values of the $m$ tests (here: 60 tests), indexed $P_{i}$ and the null hypothesis was rejected if $P_{i}$ $<i / m \times 0.05$. We also estimated $F_{\text {IS }}$ values for individual alleles in each locality, using FSTAT (version
2.9.3.2, 2002; Goudet 2001), in order to check whether deviations from $\mathrm{H}-\mathrm{W}$ were consistent with population mixing (Wahlund effect). Tests for natural selection were carried out using a simulation-based approach (Beaumont \& Nichols 1996) implemented in the Lositan Selection detection Workbench (Antao et al. 2008). Note that because of the low number of loci (6), the statistical power may be low in this test (cf. Beaumont \& Nichols 1996).

Genetic differences among localities were quantified by $F_{\mathrm{ST}}$, using Weir \& Cockerham's (1984) estimator $\theta$, over all samples and among pairs of samples. Allele frequency differences among samples were tested for with exact tests, using GenePop. We evaluated statistical 'significances' of multiple pairwise tests for heterogeneity (45 tests) using the FDR approach, as described above. In order to test for temporal stability in our data, we also performed an analysis of molecular variance (AMOVA: Excoffier et al. 2005) comparing genetic differentiation among temporal replicates within localities (Rockall and Skagerrak) to the among-localities component.

The BARRIER software (ver. 2.2; Manni et al. 2004) was used to infer and to visualize spatial genetic patterns. As input for the program, we used sample coordinates (Table 1) and pairwise $F_{\mathrm{ST}}$ estimates along all pairs of localities (pooling temporal replicates). This method identifies the coarse structure ('genetic barriers') in the data, and ranks the relative importance of these barriers, subject to the limitations that it only compares adjacent (non-disjunct) populations. As an alternative visualization tool, we estimated pairwise genetic distances ( $D_{\mathrm{A}}$ : Nei \& Chesser 1983) among samples as input data to a multi-dimensional scaling ordination (MDS) in the XL-STAT software (Addinsoft). Finally, genetic structure was further inspected with an assignment test, Geneclass 2.0 software (Piry et al. 2004) in a Bayesian approach with the option 'self-classification of reference data' where individuals are assigned to the population of most likely origin (Rannala \& Mountain 1997).

\section{Computer simulations of gene flow}

In addition to the above largely descriptive methods, we compared the pattern of pairwise $F_{\mathrm{ST}}$ values to simulated values in order to evaluate mechanistic hypotheses on population connectivity and gene flow. Two alternative (but not necessarily mutually exclusive) hypotheses were evaluated: an 'ocean drift' hypothesis, whereby gene flow is assumed to be mediated by passive drift of pelagic eggs and larvae 
with ocean currents, and a 'demographic diffusion' hypothesis, whereby gene flow is assumed to take place by dispersal among geographically proximate populations, independent of ocean currents.

For the purpose of simulations, we divided the species' habitat into a grid of 67 approximately equal sized squares or 'populations' (Figs. $1 \& 2$ ). The populations are connected through gene flow, specified in a migration matrix particular to each hypothesis. The basic idea is that the observed pattern of genetic differentiation at presumed selective neutral genes has been generated by competing dispersive (random genetic drift) and cohesive (gene flow) processes. The simulations served to determine which of the 2 hypotheses led to a pattern of genetic differences among populations that most closely resembled the observed pattern of pairwise $F_{\mathrm{ST}}$ values. Simulations took place in 3 steps: (1) construction of migration matrices for each hypothesis; (2) running of genetic simulations based on those matrices; and (3) calculating and comparing simulated and observed pairwise $F_{\mathrm{ST}}$ values.

Computer simulations were parameterized as follows. We arbitrarily populated populations (squares in Fig. 1) throughout the distribution range with 1000 individuals (2000 genes) in each, and scaled the other parameters accordingly. Because only genetic drift and migration are included, the only free parameters are time of divergence and absolute migration rates, directions, and relative rates being set by the models (below). Two localities (SK and TL; see Table 1 for location abbreviations) were isolated from each other and from all other populations in both models. These 2 presumed isolated localities carried no relevant information and were therefore excluded from further consideration in the simulation study.

In the hypothetical situation where gene flow among populations is independent of ocean currents and geographic proximity, any migration would be equal among populations and follow the so-called 'island model' (i.e. Crow \& Kimura 1970: formula 6.6.4). Hence, we chose a value for the average migration rate, $m$, to satisfy the approximate relationship $F_{\mathrm{ST}}=1 /\left(4 N_{\mathrm{e}} m+1\right)$ for the island model. Because $N_{e}=1000$ had already been chosen, and the empirically derived $F_{\mathrm{ST}}=0.0064$ (among localities IR, RA, $\mathrm{RB}, \mathrm{MR}, \mathrm{GR}$, and $\mathrm{CA}$ in the continuous habitat), the absolute number of migrants, $N_{e} m$, ought to be approximately 40 . Hence, we scaled each migration matrix to an average of 40 migrating individuals (80 genes) per population and generation.

The migration matrices specify exchange among all pairs of 67 populations and were generated as follows. For the demographic diffusion hypothesis, we simulated exchange of individuals among populations by stepwise migration, each step representing movement to a neighboring population. Direction of migration (8 different directions: north-south, eastwest, and diagonally) was determined at each dispersal event (step) by drawing a uniformly distributed random number between 1 and 8 . Only migration to occupied grids, i.e. within the species' distribution range, was considered, and migrants that ended up outside the range were returned to the last nonempty grid (i.e. the boundaries were reflective). Four different variants of the model were simulated, with maximum dispersal range of $1,2,3$, or 4 steps, yielding 4 different migration matrices for this hypothesis or model. Examples of dispersal in this model are depicted in Fig. 2a for the case of a maximum of 2 migration steps.

For the ocean drift hypothesis, we applied an existing oceanographic model (the Regional Ocean Modeling System, ROMS, version 2.1) and carried out particle drift simulations. ROMS is a 3-dimensional baroclinic general ocean model, the development of which is described in a series of papers (Song \& Haidvogel 1994, Haidvogel \& Beckmann 1999, Haidvogel et al. 2000, Shchepetkin \& McWilliams 2003, 2005). For the present study, we used velocity fields from a simulation that covers the North Atlantic (from $20^{\circ} \mathrm{S}$ ) and the Arctic. In the main region of interest, the horizontal resolution is approximately 20 to $30 \mathrm{~km}$. There were 30 generalized bottom-following $\sigma$-coordinate (s) levels, stretched to increase vertical resolution near the surface and bottom. Atmospheric forcing was obtained from the NCEP/NCAR reanalysis data (Kalnay et al. 1996, www.esrl.noaa.gov/psd/ data/gridded/data.ncep.reanalysis.html). Daily mean wind stress, and latent, sensible, downward shortwave radiative and net long wave radiative heat fluxes were applied as surface forcing after correcting for differences in model and NCEP surface conditions. The model simulation was started on 1 August 1980, initialized from fields from that date from a coarse resolution (50 $\mathrm{km}$ grid size) simulation of the North Atlantic and Arctic Oceans for the period 1948 to 2002 as described by Budgell (2005), and was updated to 2007. A time step of $900 \mathrm{~s}$ was used. Mean currents were stored every $3 \mathrm{~d}$ and used as input to a particle tracking model.

The particle tracking model was run offline with a $1 \mathrm{~h}$ time step. In the horizontal, advection was calculated using a fourth-order Runge-Kutta method adding a small uniform diffusion. The particles were fixed in the vertical at $250 \mathrm{~m}$, corresponding roughly to the observed depth of eggs and early larval stages. 
a) Demographic diffusion model

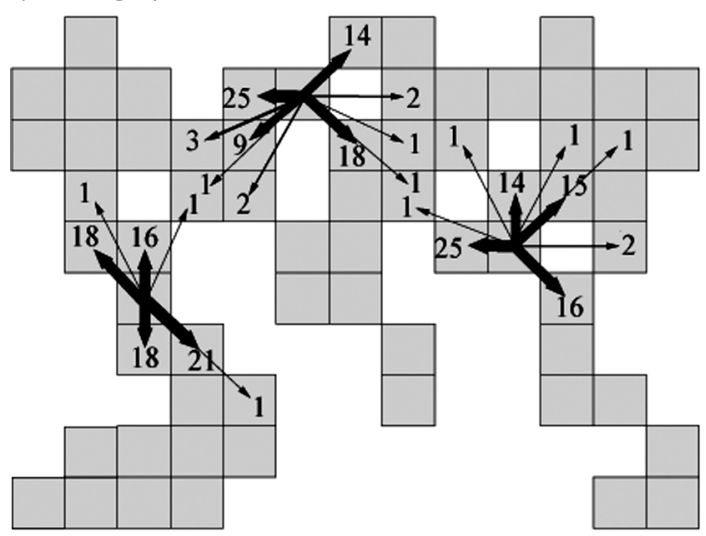

b) Ocean drift model

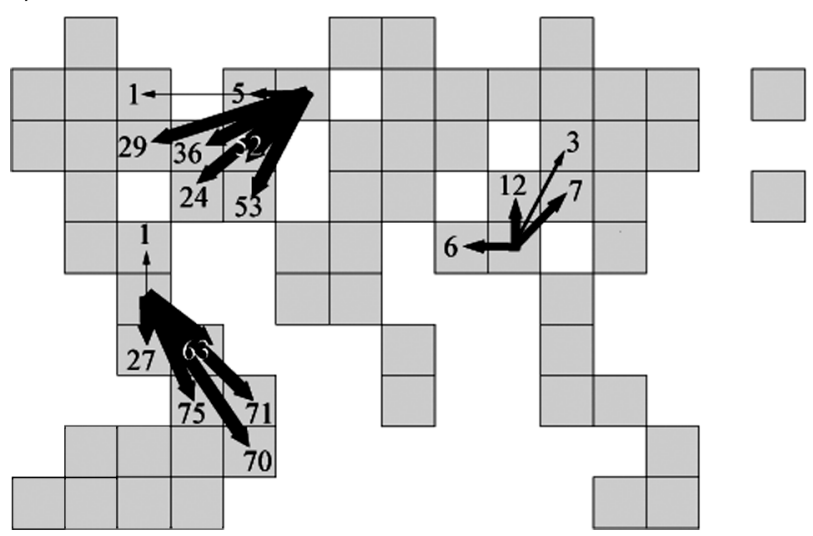

Fig. 2. Coryphaenoides rupestris. Modeled gene flow among putative 'populations' (grey squares, as in Fig. 1) as exemplified by 3 donors and their recipients. Numbers refer to genes transferred to each recipient per generation, with thickness of arrows being proportional to those numbers. (a) Demographic diffusion model, with 2 steps maximum range. (b) Ocean drift model, with $60 \mathrm{~d}$ of egg and juvenile drift

Initially, particles were distributed evenly in the whole North Atlantic from 30 to $68^{\circ} \mathrm{N}$, in all areas with bottom depth less than $2500 \mathrm{~m}$ (the approximate maximum depth range of the species). In total, approximately 25000 particles were used. Because currents at the depth of simulations $(250 \mathrm{~m})$ are relatively stable over years, we chose a single year (1998), and the particle tracking model was initialized on 1 January (assuming spawning took place in December). Particles were transported and tracked for 30, 60, 90, or $180 \mathrm{~d}$, and we noted the grid of origin for all particles that entered any other grid during the duration of tracking. The 4 different tracking durations represent 4 different assumed durations of the pelagic egg and juvenile phases. Examples of particle movements (i.e. larval drift) in the $60 \mathrm{~d}$ ocean drift model are illustrated for 3 populations (grids) in Fig. 2 b.
Genetic simulations were initiated with equal allele frequencies ( 2 alleles in frequencies of 0.5 ) in all populations, and the simulations were carried out for a number of generations (up to 240), as follows: in each generation, a number of emigrant genes were drawn by replacement (i.e. binomially) from each population, and transferred to the recipient population as specified in the migration matrix. Because the exchange among populations is generally asymmetric, excess emigration or immigration in each population was compensated for by adjusting local reproduction so as to maintain constant population sizes. Reproduction within each population was simulated by random drawing with replacement the required number of genes from the local population, and locally produced and immigrant genes were mixed and taken to represent the new generation. $F_{\mathrm{ST}}$ was calculated between pairs of populations as $F_{\mathrm{ST}}=\operatorname{Var}(q) /[q \times(1-$ $q)$ ], where $q$ is the mean allele frequency in the 2 populations and $\operatorname{Var}(q)$ is their sample variance.

Concordance between observations and predictions by the hypotheses were evaluated by Mantel tests on observed and simulated matrices of pairwise $F_{\text {ST }}$ values. Only pairs that were represented by sampled localities (except SK and TL: see above) were included in the comparison, which were based on 21 pairs, including temporal replicates.

\section{RESULTS}

Genetic variability in the total material (all samples), $H_{\mathrm{T}}$, varied among loci from 0.274 (Crup 1) to 0.981 (Crup 5), with a number of alleles ranging from 6 (Crup 2) to 83 alleles (Crup 5) in the pooled samples (Table 2). Most loci conformed to H-W expectations with average $F_{\text {IS }}$ over samples ranging from -0.1223 (Crup 2) to 0.0955 (Crup 1). Averaged across loci, the point estimate of $F_{\text {IS }}$ was only 0.0077 (Table 2), indicating little if any evidence for a Wahlund effect. Considering each sample and locus separately, exact 2-sided probability tests revealed 16 marginally significant (i.e. p value close to the alpha level of 0.05 ) deviations, representing 2 negative and 14 positive $F_{\text {IS }}$ estimates, among 60 tests. After controlling for the FDR, only a single test remained. This significance (Crup 1 in sample SK01) was also flagged by Microchecker, which did not report any further deviations in any sample or locus. Calculation and inspection of $F_{\text {IS }}$ estimates for each allele and sample indicated that the significant test results described above (before FDR correction) were largely due to unexpected homozygotes for rare alleles in a few 
Table 2. Coryphaenoides rupestris. Summary statistics for each microsatellite locus, indicating observed number of alleles (a), average gene diversity $\left(H_{\mathrm{T}}\right)$, deviation from HardyWeinberg equilibrium $\left(F_{\mathrm{IS}}\right)$, and genetic differentiation among samples $\left(F_{\mathrm{ST}}\right)$. P values refer to exact tests for allele frequency heterogeneity

\begin{tabular}{|c|c|c|c|c|c|}
\hline \multirow[b]{2}{*}{ Locus } & \multicolumn{3}{|c|}{ Genetic variability } & \multicolumn{2}{|c|}{ Genetic differentiation } \\
\hline & $\mathrm{a}$ & $H_{\mathrm{T}}$ & $F_{\mathrm{IS}}$ & $F_{\mathrm{ST}}$ & $\mathrm{p}^{\mathrm{a}}$ \\
\hline Crup1 & 8 & 0.274 & 0.0955 & 0.0104 & $<0.0001$ \\
\hline Crup2 & 6 & 0.367 & -0.1223 & 0.0158 & $<0.0001$ \\
\hline Crup3 & 68 & 0.956 & 0.0458 & 0.0215 & $<0.0001$ \\
\hline Crup5 & 83 & 0.981 & 0.0015 & 0.0066 & 0.0004 \\
\hline Crup6 & 20 & 0.796 & -0.0248 & 0.0174 & $<0.0001$ \\
\hline Crup8 & 25 & 0.853 & 0.0293 & 0.0172 & $<0.0001$ \\
\hline Average & 35 & 0.704 & 0.0077 & 0.0152 & $<0.0001$ \\
\hline
\end{tabular}

individuals, and not to a general deficiency of heterozygotes. These genotypes were repeatable, and remained unexplained, but had negligible effects on subsequent analyses of population structure. The Beaumont test did not reveal significant indications of selection at any locus (data not shown).

\section{Genetic differentiation}

The combined set of 10 samples (including temporal replicate samples) displayed statistically significant genetic differentiation, with an average $F_{\mathrm{ST}}=$ 0.0152 (Table 2: $\mathrm{p}<0.0001$, exact test for allele frequency heterogeneity). Each locus separately also displayed highly significant allele frequency differentiation among localities (cf. Table 2), with estimates of $F_{\mathrm{ST}}$ ranging from 0.0066 (at locus Crup5) to 0.0215 (Crup3).

Pairwise estimates of $F_{\mathrm{ST}}$ (Table 3) indicated that most localities were genetically divergent. Pooling temporal replicate samples, 24 out of 28 locality pairs were significant at the $5 \%$ level and 22 also at $0.5 \%$ or better. All of these pairwise significances remained (at the 5\% level) after FDR correction. Briefly, samples from the more peripheral localities, represented by Skagerrak (SK), Trondheimsleia (TL), and Canada (CA), differed highly significantly $(p<0.0001)$ from all other sites. In the central region, Greenland (GR), the mid-Atlantic Ridge (MR), and Irish Slope (IR) differed significantly or highly so from most other samples, whereas Rockall and Rosemary Bank did not. Genetic structure was also implied by the results of the individual assignment tests, which always gave the highest log-likelihood score for individuals to the locality where they were sampled (51 to $80 \%$ : diagonal in Table 4 ).

The spatial pattern of genetic divergence was characterized and illustrated graphically with BARRIER and MDS plots. BARRIER (Fig. 3) identified Canada, Trondheimsleia, Skagerrak, and Greenland, in that order, as the 4 most divergent localities. Comparatively less genetic divergence was found between the mid-Atlantic Ridge, Rockall, and Rosemary Bank. The MDS plot (Fig. 4) provided a complementary, but largely consistent view, and separated most strongly the Norwegian samples (SK01, SK08, and TL), Canada, and perhaps Greenland from the remainder.

\section{Temporal stability}

We had temporal replicate samples from 2 of the sampled localities, one representing a divergent and putative isolated population in the Skagerrak, and the other (Rockall) from the less divergent region. The AMOVA of temporal and spatial divergence among these 4 samples revealed a spatial (among groups) component $F_{\mathrm{CT}}=0.026(\mathrm{p}<0.0001)$ and

Table 3. Coryphaenoides rupestris. Estimates of pairwise genetic differentiation $\left(F_{\mathrm{ST}}\right)$ among samples (above diagonal) and $\mathrm{p}$ values from exact tests of allele frequency heterogeneity (below diagonal). P values in italics remain significant after controlling for the false discovery rate (FDR). Site abbreviations as in Table 1

\begin{tabular}{|c|c|c|c|c|c|c|c|c|c|c|}
\hline & SK01 & SK08 & TL & RA06 & RA07 & $\mathrm{RB}$ & IR & $\mathrm{MR}$ & GR & $\mathrm{CA}$ \\
\hline SK01 & - & 0.0004 & 0.0149 & 0.0228 & 0.0284 & 0.0252 & 0.0187 & 0.0229 & 0.0184 & 0.0178 \\
\hline SK08 & 0.7573 & - & 0.0188 & 0.0290 & 0.0341 & 0.0306 & 0.0274 & 0.0289 & 0.0245 & 0.0204 \\
\hline $\mathrm{TL}$ & 0.0000 & 0.0000 & - & 0.0204 & 0.0182 & 0.0183 & 0.0158 & 0.0147 & 0.0174 & 0.0205 \\
\hline RA06 & 0.0000 & 0.0000 & 0.0000 & - & 0.0044 & -0.0002 & 0.0036 & 0.0055 & 0.0033 & 0.0123 \\
\hline RA07 & 0.0000 & 0.0000 & 0.0000 & 0.0017 & - & 0.0004 & 0.0071 & 0.0015 & 0.0066 & 0.0202 \\
\hline $\mathrm{RB}$ & 0.0000 & 0.0000 & 0.0000 & 0.0154 & 0.3678 & - & 0.0042 & 0.0028 & 0.0069 & 0.0167 \\
\hline IR & 0.0000 & 0.0000 & 0.0000 & 0.0119 & 0.0082 & 0.0040 & - & 0.0078 & 0.0016 & 0.0111 \\
\hline $\mathrm{MR}$ & 0.0000 & 0.0000 & 0.0000 & 0.0097 & 0.4557 & 0.0052 & 0.0011 & - & 0.0088 & 0.0190 \\
\hline GR & 0.0000 & 0.0000 & 0.0000 & 0.0075 & 0.0983 & 0.0011 & 0.0599 & 0.0020 & - & 0.0077 \\
\hline CA & 0.0000 & 0.0000 & 0.0000 & 0.0000 & 0.0000 & 0.0000 & 0.0000 & 0.0000 & 0.0001 & - \\
\hline
\end{tabular}




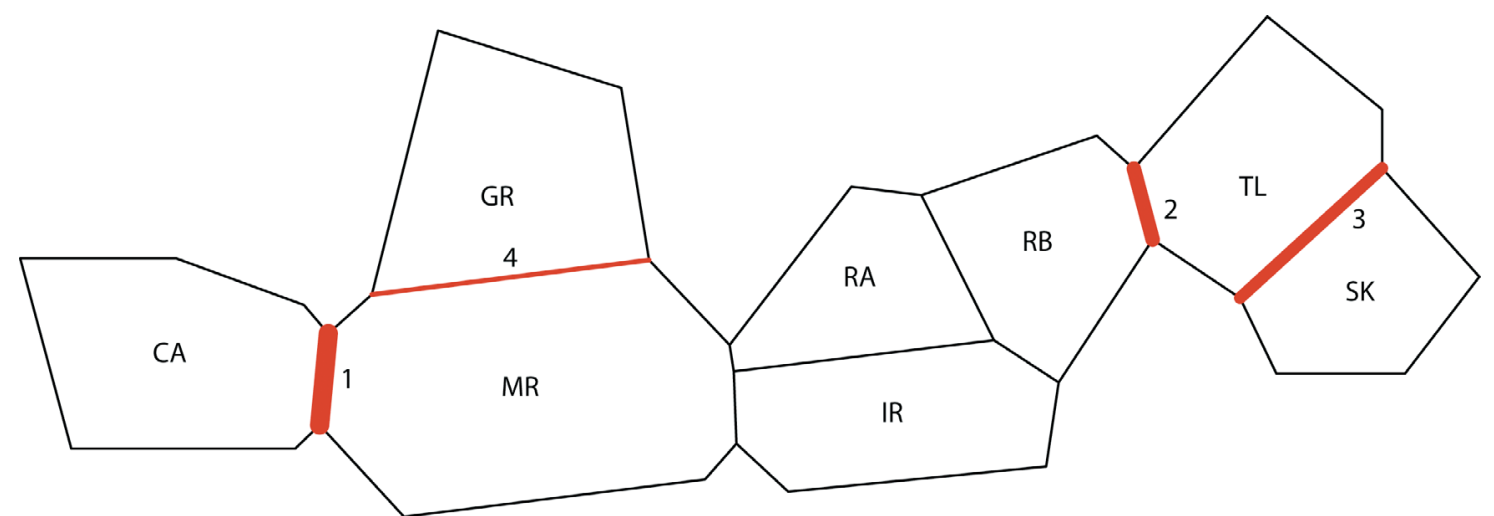

Fig. 3. Coryphaenoides rupestris. BARRIER-inferred gene flow patterns among sample localities (see Fig. 1, Table 1) based on 6 microsatellite loci. Numbers and thickness of red bars denote the rank of importance of the respective barrier (where all bars are supported by 4 or more loci)

Table 4. Coryphaenoides rupestris. Percentage of individuals assigned to (i.e. having the highest likelihood of belonging to) each of the sampled localities calculated from multilocus genotypes using the GENECLASS 2.0 software. Site abbreviations as in Table 1

\begin{tabular}{|c|c|c|c|c|c|c|c|c|c|c|}
\hline \multirow{2}{*}{ Sample } & \multirow{2}{*}{ SK01 } & \multirow[b]{2}{*}{ SK08 } & \multirow[b]{2}{*}{ TL } & \multirow[b]{2}{*}{ RA06 } & \multicolumn{2}{|c|}{ Assigned to } & \multirow[b]{2}{*}{ IR } & \multirow[b]{2}{*}{ MR } & \multirow[b]{2}{*}{ GR } & \multirow[b]{2}{*}{$\mathrm{CA}$} \\
\hline & & & & & RA07 & $\mathrm{RB}$ & & & & \\
\hline SK01 & 63 & 14 & 8 & 2 & 1 & 3 & 0 & 5 & 2 & 2 \\
\hline SK08 & 15 & 68 & 5 & 3 & 0 & 0 & 1 & 2 & 3 & 3 \\
\hline $\mathrm{TL}$ & 2 & 2 & 80 & 2 & 1 & 5 & 5 & 1 & 1 & 1 \\
\hline RA06 & 0 & 3 & 1 & 59 & 7 & 11 & 4 & 5 & 3 & 5 \\
\hline RA07 & 6 & 0 & 3 & 7 & 56 & 16 & 1 & 5 & 4 & 1 \\
\hline $\mathrm{RB}$ & 1 & 1 & 9 & 15 & 7 & 51 & 7 & 2 & 7 & 1 \\
\hline IR & 1 & 2 & 8 & 8 & 4 & 10 & 51 & 2 & 7 & 6 \\
\hline MR & 2 & 0 & 1 & 7 & 8 & 5 & 3 & 64 & 3 & 6 \\
\hline GR & 0 & 4 & 0 & 5 & 0 & 9 & 4 & 4 & 69 & 2 \\
\hline $\mathrm{CA}$ & 2 & 3 & 4 & 3 & 3 & 8 & 6 & 3 & 6 & 60 \\
\hline
\end{tabular}

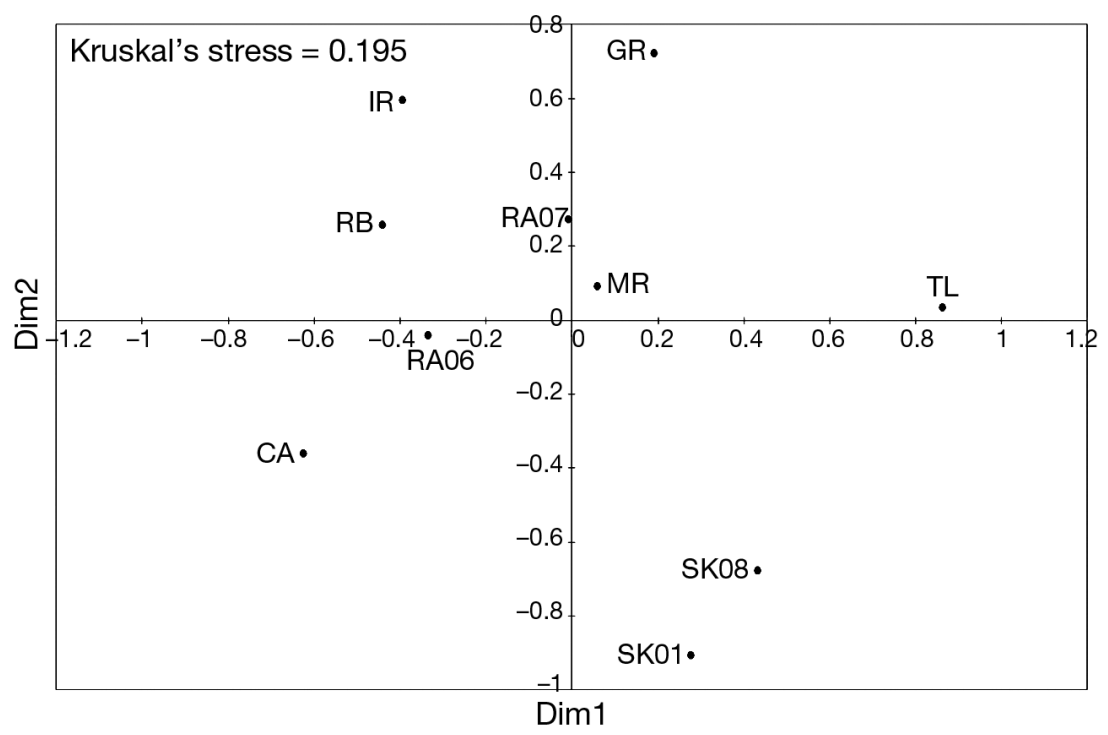

Fig. 4. Coryphaenoides rupestris. Patterns of distribution of sample localities revealed by multidimensional scaling (MDS) of the matrix of genetic distances $\left(D_{\mathrm{A} i}\right.$ Nei \& Chesser 1983; Kruskal's stress $\left.=0.195\right)$. Sample abbreviations are given in Table 1 temporal (within groups) component $F_{\mathrm{SC}}=0.0025(\mathrm{p}=0.08)$. Here considering each locality separately, the Skagerrak samples, collected in 2001 and 2008, were similar $\left(F_{\mathrm{ST}}=0.0004\right.$, Table 3) and not significantly different $(p=0.7573$; exact heterogeneity test), thus verifying the genetic integrity of this locality. At Rockall, the 2 temporal replicates from 2006 and 2007 were more different $\left(F_{\mathrm{ST}}=\right.$ $0.0044 ; \mathrm{p}=0.0017)$. However, the temporal replicates from Rockall were not sampled at exactly the same site (separated by ca. $180 \mathrm{~km}$ ), and the observed difference may reflect some spatial heterogeneity. The difference between the Rockall 2006 and 2007 samples was at the same level as those between Rockall and the 2 other localities on the European slope, i.e. from $F_{\mathrm{ST}}=-0.0002$ with Rosemary Bank to 0.0071 with the Irish Slope (Table 3). Hence, divergence within European Slope sites seemed generally low.

\section{Comparison of genetic data with models of dispersal and gene flow}

Pairwise observed $F_{\mathrm{ST}}$ values (Table 3) for the continuous habitat (i.e. excluding SK and TL) were compared to the computer-simulated gene flow models in Fig. 5, depicting the situation after 120 generations. Clearly, the ocean drift model (right 
panels) failed to recover the observed pattern of differentiation. The lack of fit probably arose from this model allowing too little gene flow (cf. Fig. 2b) among the central and Eastern Atlantic sites (MR, RA, and RB), thus predicting larger $F_{\mathrm{ST}}$ among these localities than observed. During simulations, this resulted in an overall negative but non-significant Mantel test in early generations (at 30 generations: the standardized Mantel $z$-statistic, r, varied from

\section{Demographic diffusion model}
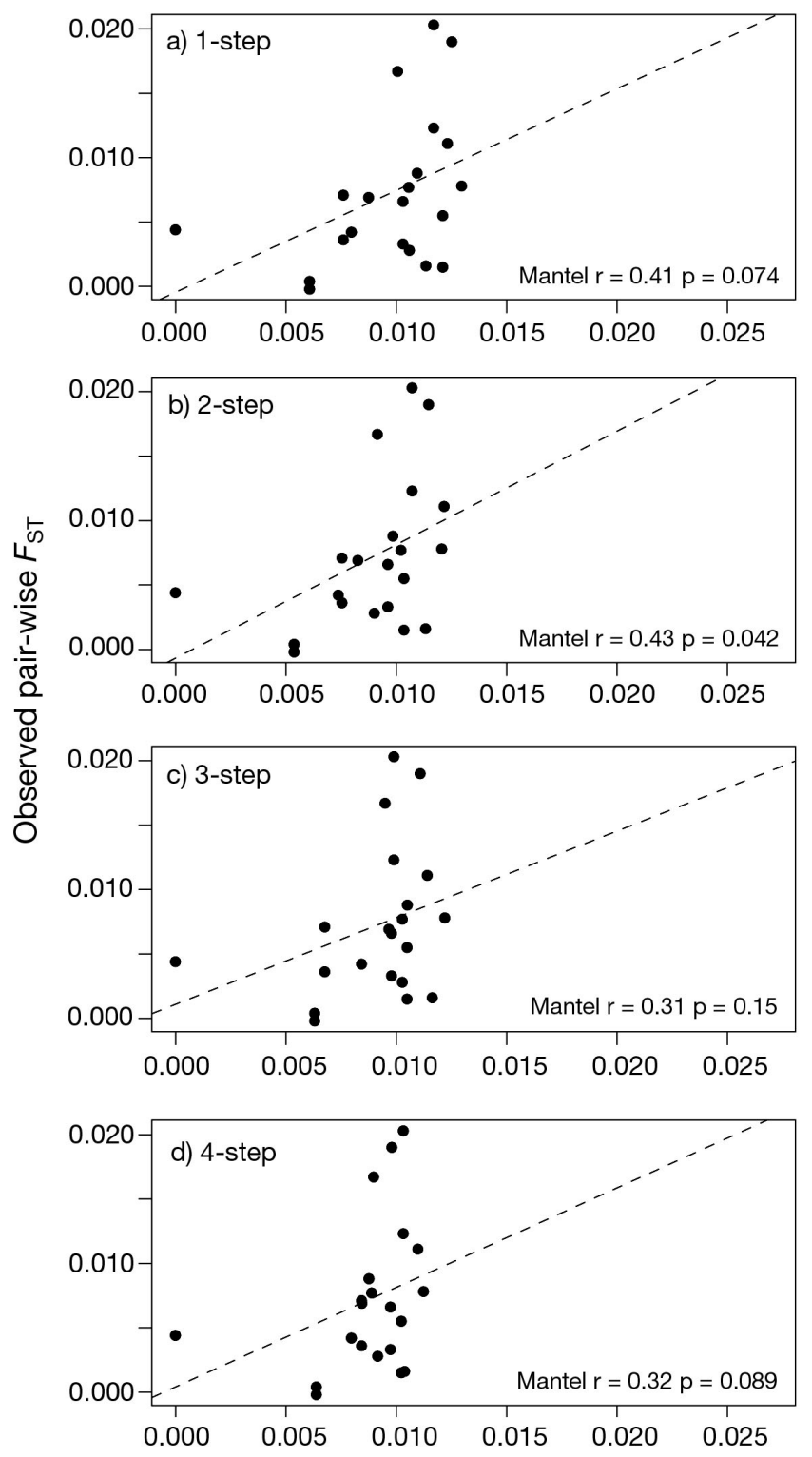

-0.1 to -0.2 , depending on drift duration: data not shown) that tended towards 0 with increasing time for all 4 larval drift durations (Fig. 5e-h). None of these comparisons was statistically significant from 0 .

The demographic diffusion model predicted a better fit to observations than did the ocean drift model (Fig. 5a-d). Correlations between observed and simulated $F_{\mathrm{ST}}$ values were positive for all 4 model versions at all times, and significantly so for the 2-step
Ocean drift model
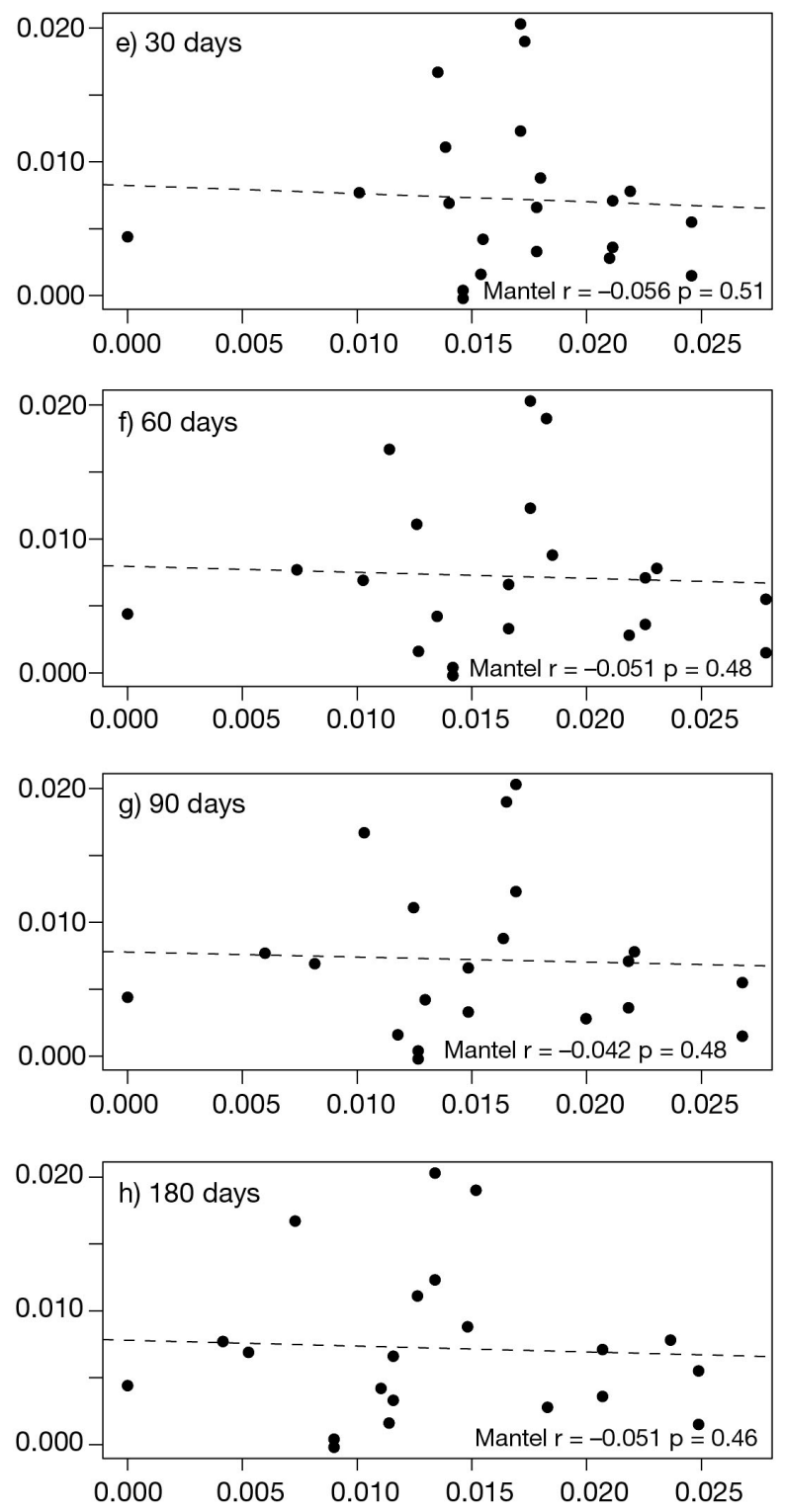

Simulated pair-wise $F_{\mathrm{ST}}$

Fig. 5. Coryphaenoides rupestris. Comparisons of observed (vertical axes) and simulated (in generation 120; horizontal axes) $F_{\mathrm{ST}}$-values among pairs of samples from the continuous habitat (i.e. excluding samples SK and TL). Two different dispersal models each with 4 different parameter values ( $\mathrm{a}-\mathrm{d}$ and $\mathrm{e}-\mathrm{h}$, respectively) are compared. $\mathrm{r}$ and $\mathrm{p}$ values refer to the Mantel test of observed and simulated pairwise values, and the dotted line is the linear regression 
version at 120 generations (Fig. 5a-d). All 4 became nominally significant in later generations ( $\mathrm{r}$ from 0.4 to 0.5 ; p from 0.049 to 0.021 in generation 240: not shown) with the 2-step version yielding a marginally better fit at $r=0.5 ; p=0.021$. Because dispersal in the demographic diffusion model was restricted geographically (cf. Fig. 2a), the fit with observations indicated an isolation by distance effect on genetic structure within the continuous habitat. In absolute terms, the best fit was not very high, however, perhaps because the model predicted too little gene flow among the neighboring RA and RB localities in the east and too much to $\mathrm{CA}$ in the west.

\section{DISCUSSION}

Based on samples from throughout the species' range and using 6 polymorphic and most likely neutral microsatellite loci, we found significant genetic structure in the roundnose grenadier. The overall estimate of genetic differentiation was elevated by samples from the periphery of the species' distribution range. The central area of distribution shows less pronounced genetic structure, though still statistically significant for many sites, in agreement with previous reports (White et al. 2010). Contrary to that work, we found no evidence for selection operating on any locus, but this negative result may reflect limited sampling in very deep localities in our case.

The most divergent localities were Skagerrak and Trondheimsleia (a shelf trough within the island archipelago of mid-Norway), 2 localities representing topographically isolated basins surrounded by shallow sills or landmasses. Sill depths are $275 \mathrm{~m}$ (Skagerrak) or shallower (Trondheimsleia), and probably too shallow to be crossed by demersal life stages of grenadier. Deep-sea circulation features may further retain eggs and larvae within these basins, and at least the Skagerrak is known to have a persistent cyclonic deepwater circulation (e.g. Rohde 1989). Hence, these 2 sites most likely contain largely isolated populations, and the combination of isolation and local genetic drift may explain their elevated genetic differentiation.

Apart from distinct populations in marginal localities (and probably also in other fjords of Norway where the species is known to occur), the more or less continuous potential range of the grenadier comprising the entire ocean margin of the Northeast and Northwest Atlantic, the Scotland to Greenland Ridges, and the mid-Atlantic Ridge seems less differentiated. It is presently unclear whether (adult) grenadiers disperse across this region in numbers sufficient to maintain genetic differentiation at the observed low level, as no such dispersal has been observed. On the other hand, only about 40 effective dispersers per generation among putative local populations are enough to maintain the observed genetic similarity (see 'Materials \& methods'). Given the rather inaccessible habitat, it is highly doubtful that such slight numbers would have been detected.

Complementing our genetic analyses, Longmore et al. $(2010,2011)$ conducted a trace element analysis of otoliths from a sub-set of 20 to 24 individuals from each of 4 sample sites (mid-Atlantic Ridge, Rockall, Irish Slope, and the Skagerrak; same samples as used in the genetic analyses), and were able to classify 74 to $100 \%$ of adult individuals to the correct site (Longmore et al. 2011). The genetic assignments reported in the present study (Table 4) yielded qualitatively similar findings, although with somewhat lower proportions of correct assignment (51 to $83 \%$ to site of capture: pooling temporal samples).

The somewhat better fit between observed genetic structure and the demographic diffusion model (cf. Fig. 5) suggested that dispersal in the roundnose grenadier is largely restricted to short-range movements independent of ocean currents. This observation may seem surprising given the extended pelagic egg and juvenile stages of this species, which might be expected to result in transport of individuals over considerable distances (cf. Fig. 2b).

A plausible explanation for the apparent lack of importance of long-distance transport of eggs and larvae may be that grenadier larvae are not passive particles, and that their depth distribution and behaviour may reduce the risk of being advected by ocean currents. Merrett \& Haedrich (1997) showed how the depth distribution of pelagic juveniles increased with increasing size, and also indicated that juveniles tend to occur deeper as they grow larger. Results from otolith microchemistry analysis of roundnose grenadiers also suggest that larvae and juveniles move to deeper waters as the midwater phase progresses (Longmore et al. 2011). The move would probably position the juveniles in weaker current regimes and reduce the risk of being advected away from their place of origin. Examples of restricted larval dispersal in shallow-living (0-200 $\mathrm{m}$ in the neritic zone) fishes in the North Atlantic are found associated with regional circulation features (e.g. Sinclair 1988, Buonaccorsi et al. 2002, Cowen 2002, Ciannelli et al. 2010).

Our findings do not lend support to a hypothesized single 'superpopulation' in the entire distribution range, nor that of (only) 2 self-sustaining populations 
in the North Atlantic and on the European slope, as proposed by some earlier workers (summarized by Shibanov \& Vinnichenko 2008). Instead, our genetic results, as exemplified by highly significant allele frequency differences (Table 3), coincide with previous genetic studies (Logvinenko et al. 1983, Dushchenko \& Savvatimskii 1987) and with otolith microchemistry results (Longmore et al. 2011), and suggest the existence of several, partly interconnected, populations throughout the species' range. This conclusion seems in line with one of the earlier Russian theories (Troyanovsky \& Lisovsky 1995, Shibanov \& Vinnichenko 2008), suggesting several populations inhabiting different subareas.

In order to put the genetic structure of the roundnose grenadier into perspective, we compared $F_{\mathrm{ST}}$

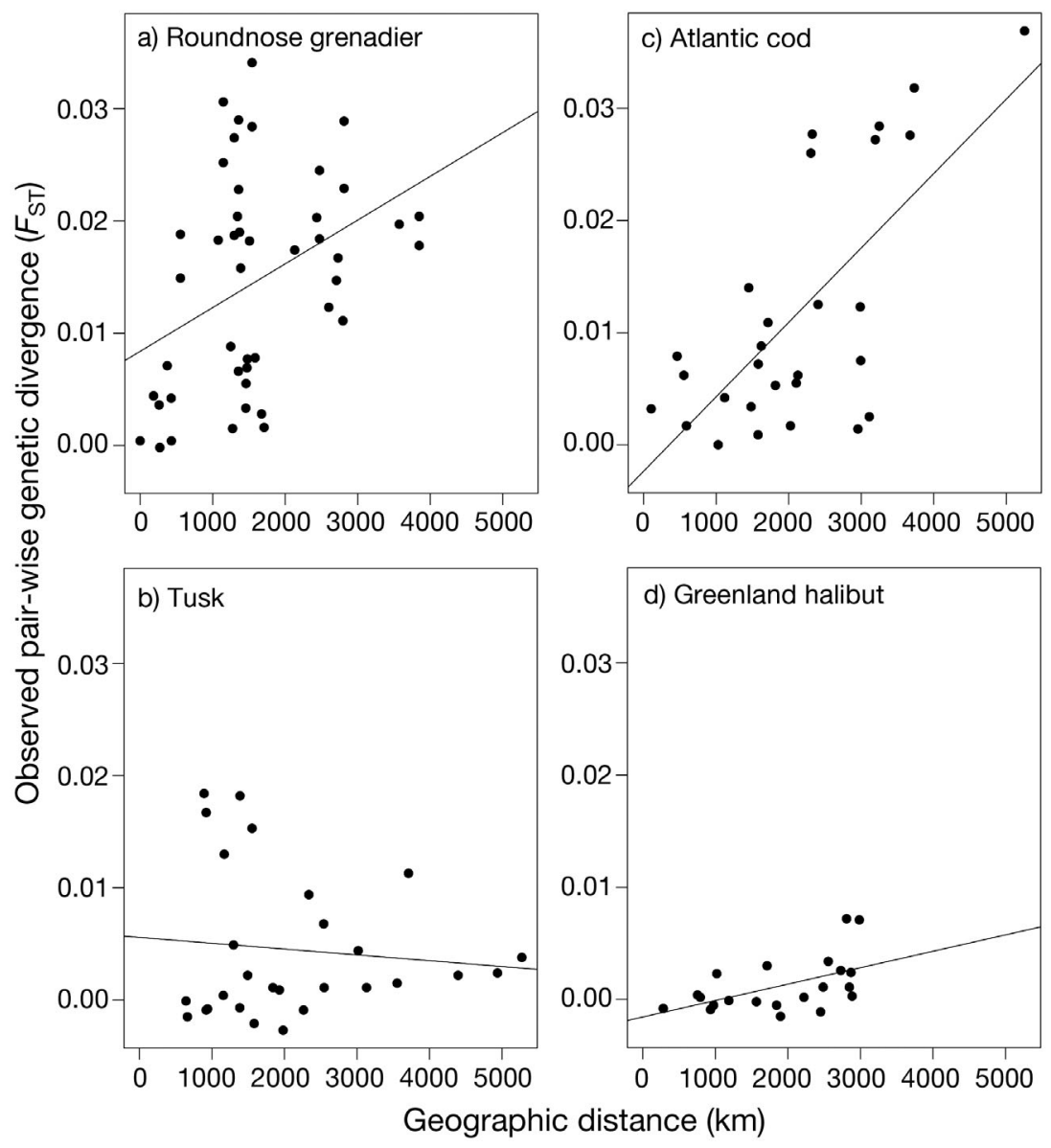

Fig. 6. Comparative plots of genetic diversity $\left(F_{\mathrm{ST}}\right)$ between samples separated at different geographic (Euclidean) distances for North Atlantic fishes: (a) roundnose grenadier Coryphaenoides rupestris (this study: all samples included); (b) tusk Brosme brosme (Knutsen et al. 2009); (c) Atlantic cod Gadus morhua (recalculated from allele frequencies in Appendix I of O'Leary et al. 2007, excluding locus Gmo 34 and the Baltic sample); (d) Greenland halibut Reinhardtius hippoglossoides (recalculated from Knutsen et al. 2008, excluding 3 loci with null alleles). The lines indicate the linear regression of $F_{\mathrm{ST}}$ on distance. The scale is the same in all figures estimates among sample pairs over similar geographic scales for other fishes with a northern, transAtlantic distribution (Fig. 6). Quantitatively, genetic divergence in the roundnose grenadier is similar to that observed in Atlantic cod (O'Leary et al. 2007, reanalyzed excluding locus Gmo 34, which is potentially under selection in the Barents Sea: Nielsen et al. 2006, and also excluding the isolated Baltic sample), while larger than in 2 other deep sea fishes (Greenland halibut: Knutsen et al. 2007; tusk: Knutsen et al. 2009). Qualitatively, the patterns differ among species, with Atlantic cod and Greenland halibut displaying a stronger isolation by distance trend, i.e. $F_{\mathrm{ST}}$ values increase more linearly with geographic distance. In the roundnosed grenadier, as in the tusk, factors other than distance, such as bathymetric barriers, seem to more strongly affect genetic divergence and population connectivity than in the more mobile Atlantic cod and Greenland halibut.

\section{Management implications}

Many deep-sea fishes of commercial interest are widely distributed both in deep shelf areas, on continental slopes, and on the mid-ocean ridges and seamounts. Fisheries for the roundnose grenadier were conducted in many parts of its range, starting in the 1960s, increasing in the 1980s, and declining in the most recent years due to low profitability and stricter management (e.g. Atkinson 1995, Troyanovsky \& Lisovsky 1995, Lorance et al. 2008, Shibanov \& Vinnichenko 2008). Management advice depends on an understanding of population structure to define management units, i.e. 'stocks,' and their geographical ranges. Our finding of genetic differentiation patterns demonstrates that the roundnose grenadier is structured at various geographic scales. Parts of this structure, notably in peripheral (CA) and bathymetrically isolated basins (SK and TL), obviously represent distinct biological populations with limited present connectivity. In other areas, off the British Isles (IR, RA, and RB), the magnitude of genetic structure is 
weaker and less clearly defined. This lack of definition could reflect that samples from this area represent a single, widespread population. On the other hand, a recent study of coastal Atlantic cod (Knutsen et al. 2011) reported highly restricted connectivity (less than $0.5 \%$ adult fish exchanged per year) among 2 populations that were only weakly differentiated at microsatellite loci (average $F_{\mathrm{ST}}=0.0037$ ). This level is similar to what we found herein among, e.g. GR, MR, RA, and RB (Table 3), and we cannot exclude the possibility that some of these sites represent distinct biological populations. Moreover, this study does not provide a full account of populations throughout the species' range. Whether the possibly many different populations of roundnose grenadier require separate management strategies depends on many factors not considered here, e.g. spatial heterogeneity in population dynamics, exploitation history, and an evaluation of effectiveness of the already implemented wide-ranging management actions.

Aknowledgements. The Norwegian Research Council (through the European Science Foundation [www.esf.org] EUROCORES project DEECON), the Norwegian Ministry of Fishery and Coastal Affairs, and the MAR-ECO project (www.mar-eco.no), a field project under the Census of Marine Life program, provided support for this study. We thank K. Enersen and H. Sannæes for technical assistance in the laboratory. We are also grateful to colleagues and projects who provided tissue samples: F. Neat, Marine Scotland, Aberdeen; P. Rask Møller, Zoological Museum, Copenhagen; R. Bowering, Department of Fisheries and Oceans, St. Johns, Newfoundland. Four anonymous reviewers provided valuable comments on an earlier version of this manuscript.

\section{LITERATURE CITED}

Almany GR, Berumen ML, Thorrold SR, Planes S, Jones GP (2007) Local replenishment of coral reef fish populations in a marine reserve. Science 316:742-744

Antao T, Lopes A, Lopes RJ, Beja-Pereira A, Luikart G (2008) LOSITAN: a workbench to detect molecular adaptation based on a $F_{s t}$-outlier method. BMC Bioinformatics 9:323

Atkinson DB (1995) The biology and fishery of roundnose grenadier (Coryphaenoides rupestris Gunnerus, 1765) in the North West Atlantic. In: Hopper AG (ed) Deep-water fisheries of the North Atlantic Oceanic Slope. NATO ASI Series, Series E: applied sciences, Vol 296. Kluwer Academic Publishers, London, p 51-112

- Beaumont MA, Nichols RA (1996) Evaluating loci for use in the genetic analysis of population structure. Proc R Soc Lond B Biol Sci 263:1619-1626

Benjamini Y, Hochberg Y (1995) Controlling the false discovery rate: a practical and powerful approach to multi- ple testing. J R Stat Soc B 57:289-300

Bergstad OA (1990) Distribution, population structure, growth and reproduction of the roundnose grenadier Coryphaenoides rupestris (Pisces: Macrouridae) in the deep waters of the Skagerrak. Mar Biol 107:25-39

Bergstad OA, Gordon JDM (1994) Deep-water ichthyoplankton of the Skagerrak with special reference to Coryphaenoides rupestris Gunnerus, 1765 (Pisces: Macrouridae) and Argentina silus (Ascanius, 1775) (Pisces, Argentinidae). Sarsia 79:33-43

Bergstad OA, Høines ÅS, Orlov A, Iwamoto T, Galbraith J, Byrkjedal I, Uiblein F (2008) Species composition and abundance patterns of grenadiers on the Mid-Atlantic Ridge between Iceland and the Azores. Am Fish Soc Symp 63:65-80

Budgell WP (2005) Numerical simulation of ice-ocean variability in the Barents Sea region: towards dynamical downscaling. Ocean Dyn 55:370-387

Buonaccorsi VP, Kimbrell CA, Lynn EA, Vetter RD (2002) Population structure of copper rockfish (Sebastes caurinus) reflects postglacial colonization and contemporary patterns of larval dispersal. Can J Fish Aquat Sci 59: 1374-1384

Caley MJ, Carr MH, Hixon MA, Hughes TP, Jones GP, Menge BE (1996) Recruitment and the local dynamics of open marine populations. Annu Rev Ecol Syst 27: 477-500

> Ciannelli L, Knutsen H, Olsen EM, Espeland SH and others (2010) Maintenance of small-scale genetic structure in a marine population in relation to water circulation and egg characteristics. Ecology 91:2918-2930

Cowen RK (2002) Larval dispersal and retention, and consequences for population connectivity. In: Sale PF (ed) Coral reef fishes. Dynamics and diversity in a complex ecosystem. Academic Press, New York, NY, p 149-170

Cowen RK, Paris CB, Srinivasan A (2006) Scaling of connectivity in marine populations. Science 311:522-527

Crow J, Kimura M (1970) An introduction to population genetics theory. Harper \& Row, New York, NY

Dushchenko VV, Savvatimskii PI (1987) Intraspecific structure of the rock grenadier Coryphaenoides rupestris Gunnerus from the North Atlantic: variability of local groups and prerequisites of their formation. Vopr Ikhtiol 27:784-793 (in Russian)

Eliassen JE (1983) Distribution and abundance of roundnose grenadier (Coryphaenoides rupestris Gunnerus; Gadiformes, Macrouridae) in northern and mid-Norway. ICES Meet Pap G 43:1-24

Excoffier L, Laval G, Schneider S (2005) Arlequin ver. 3.0: an integrated software package for population genetics data analysis. Evol Bioinform Online 1:47-50

Froese R, Pauly D (2000) FishBase 2000: concepts, design and data sources. ICLARM, Los Baños, Laguna

Geistdoerfer P (1986) Macrouridae. In: Whitehead PJP, Bauchot ML, Hureau JC, Nielsen J, Tortonese E (eds) Fishes of the North-eastern Atlantic and the Mediterranean, Vol II. UNESCO, Paris, p 644-676

Goudet J (2001) FSTAT, a program to estimate and test gene diversities and fixation indices version 2.9.3. Available at www2.unil.ch/popgen/softwares/fstat.htm

Haedrich RL (1974) Pelagic capture of the epibenthic rattail Coryphaenoides rupestris. Deep-Sea Res I 25:705-720

Haidvogel DB, Beckmann A (1999) Numerical ocean circulation modeling. Imperial College Press, London

Haidvogel DB, Arango HG, Hedstrom K, Beckmann A, 
Malanotte-Rizzoli P, Shchepetkin AF (2000) Model evaluation experiments in the North Atlantic Basin: simulations in nonlinear terrain-following coordinates. Dyn Atmos Oceans 32:239-281

ICES (International Council for the Exploration of the Sea) (2002) Report of the ICES Advisory Committee on Fishery Management. ICES, Copenhagen

> Jones GP, Milicich MJ, Emslie MJ, Lunow C (1999) Selfrecruitment in a coral reef fish population. Nature 402 : 802-804

Jorde PE, Knutsen H, Espeland SH, Stenseth NC (2007) Spatial scale of genetic structuring in coastal cod Gadus morhua and geographic extent of local populations. Mar Ecol Prog Ser 343:229-237

> Jørgensen HB, Hansen MM, Bekkevold D, Ruzzante DE, Loesccke V (2005) Marine landscapes and population genetic structure of herring (Clupea harengus L.) in the Baltic Sea. Mol Ecol 14:3219-3234

Kalnay E, Kanamitsu M, Kistler R, Collins W and others (1996) The NCEP/NCAR 40-Year Reanalysis Project. Bull Am Meteorol Soc 77:437-471

> Kenchington EL, Patwary MU, Zouros E, Bird CJ (2006) Genetic differentiation in relation to marine landscape in a broadcast-spawning bivalve mollusc (Placopecten magellanicus). Mol Ecol 15:1781-1796

Knutsen H, Jorde PE, Albert OT, Hoelzel AR, Stenseth NC (2007) Population genetic structure in the North Atlantic Greenland halibut: influenced by oceanic current systems? Can J Fish Aquat Sci 64:857-866

Knutsen H, Le Goff-Vitry M, Fiani D, Hoelzel AR (2008) Isolation and characterization of microsatellite loci in the deep-sea marine fish, the roundnose grenadier (Coryphaenoides rupestris). Mol Ecol Resour 8:993-995

Knutsen H, Jorde PE, Sannaes H, Hoelzel AR and others (2009) Bathymetric barriers promoting genetic structure in the deepwater demersal fish tusk (Brosme brosme). Mol Ecol 18:3151-3162

Knutsen H, Olsen EM, Jorde PE, Espeland SH, Andre C, Stenseth NC (2011) Are low but statistically significant levels of genetic differentiation in marine fishes 'biologically meaningful'? A case study of coastal Atlantic cod. Mol Ecol 20:768-783

Logvinenko BM, Nefedov GN, Massal'skaya LM, Polyanskaya IB (1983) A population analysis of rock grenadier based on the genetic polymorphism of non-specific esterases and myogenes. Can Transl Fish Aquat Sci 5406:1-16

> Longmore C, Fogarty K, Neat F, Brophy D, Trueman C, Milton A, Mariani S (2010) A comparison of otolith microchemistry and otolith shape analysis for the study of spatial variation in a deep-sea teleost, Coryphaenoides rupestris. Environ Biol Fishes 89:591-605

Longmore C, Trueman CN, Neat F, O'Gorman EJ, Milton JA, Mariani S (2011) Otolith geochemistry indicates lifelong spatial population structuring in a deep-sea fish, Coryphaenoides rupestris. Mar Ecol Prog Ser 435: 209-224

Lorance P, Bergstad OA, Large PA, Gordon JDM (2008) Grenadiers in the North East Atlantic-distribution, biology, fisheries and their impacts, and developments in stock assessment and management. Am Fish Soc Symp 63:365-397

> Manel S, Schwartz MK, Luikart G, Taberlet P (2003) Landscape genetics: combining landscape ecology and population genetics. Trends Ecol Evol 18:189-197
Manni F, Guérard E, Heyer E (2004) Geographic patterns of (genetic, morphologic, linguistic) variation: how barriers can be detected by using Monmonier's algorithm. Hum Biol 76:173-190

- McCairns RJS, Bernatchez L (2008) Landscape genetic analyses reveal cryptic population structure and putative selection gradients in a large-scale estuarine environment. Mol Ecol 17:3901-3916

Merrett NR (1978) On the identity and pelagic occurrence of larval and juvenile stages of rattail fishes (family Macrouridae) from $60^{\circ} \mathrm{N}, 20^{\circ} \mathrm{W}$ and $53^{\circ} \mathrm{N}, 20^{\circ} \mathrm{W}$. DeepSea Res 25:147-160

Merrett NR, Haedrich RL (1997) Deep-sea demersal fish and fisheries. Chapman and Hall, London

Nei M, Chesser RK (1983) Estimation of fixation indices and gene diversities. Ann Hum Genet 47:253-259

> Nielsen EE, Hansen MM, Meldrup D (2006) Evidence of microsatellite hitch-hiking selection in Atlantic cod (Gadus morhua L.): implications for inferring population structure in non-model organisms. Mol Ecol 15:3219-3229

> O'Leary DB, Coughlan J, Dillane E, McCarthy TV, Cross TF (2007) Microsatellite variation in cod Gadus morhua throughout its geographic range. J Fish Biol 70:310-335

Pechenik LN, Troyanovsky FM (1971) Trawling resources on the North-Atlantic continental slope. Cat No 5977. Israel Program for Scientific Translations, Jerusalem

> Pineda J, Hare JA, Sponagule S (2007) Larval transport and dispersal in the coastal ocean and consequences for population connectivity. Oceanography 20:22-39

Piry S, Alapetite A, Cornuet JM, Paetkau D, Baudouin L, Estoup A (2004) GeneClass2: a software for genetic assignment and first-generation migrant detection. J Hered 95:536-539

Planes S, Jones GP, Thorrold SR (2009) Larval dispersal connects fish populations in a network of marine protected areas. Proc Natl Acad Sci USA 106:5693-5697

> Rannala B, Mountain JL (1997) Detecting immigration by using multilocus genotypes. Proc Natl Acad Sci USA 94: 9197-9201

Rohde J (1989) The large scale mixing and the estuarine circulations in the Skagerrak; calculations from observations of salinity and velocity fields. Tellus 41:436-446

> Rousset F (2008) GENEPOP'007: a complete re-implementation of the GENEPOP software for Windows and Linux. Mol Ecol Resour 8:103-106

Scott WB, Scott MG (1988) Atlantic fishes of Canada. Can Bull Fish Aquat Sci 219:1-731

Selkoe KA, Watson JR, White C, Ben Horin T and others (2010) Taking the chaos out of genetic patchiness: Seascape genetics reveals ecological and oceanographic drivers of genetic patterns in three temperate reef species. Mol Ecol 19:3708-3726

Shchepetkin AF, McWilliams JC (2003) A method for computing horizontal pressure-gradient force in an oceanic model with a nonaligned vertical coordinate. J Geophys Res 108:3090 doi:10.1029/2001JC001047

Shchepetkin AF, McWilliams JC (2005) The regional ocean modeling system (ROMS): a split-explicit, free-surface, topography-following-coordinate oceanic model. Ocean Model 9:347-404

Shibanov VN, Vinnichenko VI (2008) Russian investigations and the fishery of roundnose grenadier in the North Atlantic. Am Fish Soc Symp 63:399-412

Sinclair M (1988) Marine populations: an essay on population regulation and speciation. University of Washington 
Press, Seattle, WA

Song Y, Haidvogel D (1994) A semi-implicit ocean circulation model using a generalized topography-following coordinate system. J Comput Phys 115:228-244

Troyanovsky FM, Lisovsky SF (1995) Russian (USSR) fisheries research in deep waters (below $500 \mathrm{~m}$ ) in the North Atlantic. In: Hopper AG (ed) Deep-water fisheries of the North Atlantic Oceanic Slope. NATO ASI Series, Series E: applied sciences, Vol 296. Kluwer Academic Publishers, London, p 357-366

Van Oosterhout C, Hutchinson WF, Wills DPM, Shipley P (2004) MICRO-CHECKER: software for identifying and correcting genotyping errors in microsatellite data. Mol Ecol Notes 4:535-538

Editorial responsibility: Hans Heinrich Janssen, Oldendorf/Luhe, Germany
Vinnichenko VI, Khlivnoy VN (2008) New data on the distribution of young roundnose grenadier in the North Atlantic. Am Fish Soc Symp 63:119-124

> Waples RS, Gaggiotti O (2006) What is a population? An empirical evaluation of some genetic methods for identifying the number of gene pools and their degree of connectivity. Mol Ecol 15:1419-1439

- Weir BS, Cockerham CC (1984) Estimating F-statistics for the analysis of population structure. Evolution 38: $1358-1370$

White TA, Stamford J, Hoelzel AR (2010) Local selection and population structure in a deep-sea fish, the roundnose grenadier (Coryphaenoides rupestris). Mol Ecol 19: 216-226

Submitted: August 24, 2011; Accepted: March 19, 2012 Proofs received from author(s): July 9, 2012 